\title{
History of Numeracy Education and Training for Print Journalists in England
}

Steven Harrison

Liverpool John Moores University, s.harrison1@ljmu.ac.uk

Follow this and additional works at: https://digitalcommons.usf.edu/numeracy

Part of the Curriculum and Instruction Commons, and the Science and Mathematics Education Commons

\section{Recommended Citation}

Harrison, Steven. "History of Numeracy Education and Training for Print Journalists in England."

Numeracy 7, Iss. 2 (2014): Article 2. DOI: http://dx.doi.org/10.5038/1936-4660.7.2.2 


\title{
History of Numeracy Education and Training for Print Journalists in England
}

\begin{abstract}
If the history of journalism education has been a footnote to accounts of the profession's development, then the history of numeracy training for journalists must be considered a footnote to a footnote. Despite the universally acknowledged centrality of numbers to a clear understanding of the world, many journalism students and entrants are proudly number-phobic; it is even suggested that an aversion to maths is a key reason why some choose journalism as a career. This study traces the development of numeracy education for journalists in England. It is only with the incipient professionalisation of journalism from the mid-19th century that numeracy becomes problematic, partly because of the rise of mass education in the 1870 s and partly because of the changing nature of news. Yet - drawing on manuals, biographies and personal accounts - it turns out it was as late as the 1940s before any systematic plan to counter the prevailing literary leanings of journalists was proposed, and a further 30 years before this took root in the academy. The picture today is mixed, with professional and accreditation bodies, industry-sponsored initiatives, non-journalism organisations and academic institutions all playing a part. The consequences of this are evident in misreported or under-reported news stories. The lack of a coherent approach to numeracy training, or even agreement as to what it should comprise, exposes a critical weakness in journalism's mission to explain.
\end{abstract}

\section{Keywords}

numeracy, journalism, education, training, quantitative literacy, data journalism

\section{Creative Commons License}

$$
\text { (c) (i) (8) }
$$

This work is licensed under a Creative Commons Attribution-Noncommercial 4.0 License

\section{Cover Page Footnote}

Steve Harrison is a senior lecturer in journalism at Liverpool John Moores University, UK, where he specialises in digital media and media production. Having worked on regional daily newspapers for over 25 years, he has a strong interest in numeracy and journalism. He is currently researching how journalists' lack of numeracy skills affects the selection and transmission of news. 


\section{Introduction}

Ours is a world shot through with numbers; they are the threads which weave together political discourse, public debate and social policy. Veteran newspaperman David Randall observed: “If you don't know enough to question data, then you really are impotent as a journalist” (Randall 2007). The doyen of quantitative reporting Philip Meyer echoed the sentiment when he wrote that we journalists "write with words, but we must learn to read in numbers" (Meyer 2002: 145). Yet the journalists who report on and interpret this world are rarely drawn from the ranks of the mathematically inclined; there is anecdotal evidence that many entrants into the profession do so expressly to avoid tangling with numbers ${ }^{1}$ (Mencher 1995, cited in Maier 2002). Maier draws the conclusion that: "Innumeracy in professional practice apparently has roots in journalism education, as the discipline tends to attract students who lack the skills and the motivation to use numbers effectively" (Maier 2002). Ranney et al. (2008) add that: "Some journalists are avowedly 'numberphobic' - trying to 'write around the numbers,' thus yielding pieces insufficient in rich, memorable, or accurate information”.

The emphasis for journalism entrants has traditionally been on a liberal arts education - indeed, one respected commentator has gone so far as to declare that "the natural academic home of journalism is among the humanities and the humanistic social sciences" (Carey 2000). Until relatively recently, this type of education was unsuited to delivering numeracy as a core element within its curriculum: "Classical education in the US and Europe did not focus on competencies such as numeracy until the latter part of the twentieth century when numeracy became a concern in the United Kingdom and in the US" (Madison and Steen 2008). This makes it all the more crucial that journalists and journalism students are trained in how to work with numbers.

Of course, it is widely recognised that facility with number is a trait desirable in all graduates, not just those studying journalism. For example, in his report into the future of higher education, numeracy was described by Lord Dearing as one of the four basic skills which are "key to the future success of graduates whatever they intend to do in later life” (Dearing Report 1997: 133). Yet a recent survey by the Organisation for Economic Co-operation and Development (OECD 2013) showed that England's 16-24 year olds languished 21st in a list of 24 countries for numeracy. This paper understands

\footnotetext{
${ }^{1}$ Mencher's anecdote concerns students at Columbia University's Graduate School of Journalism. On being asked why they performed so poorly in a maths test, the unanimous reply was: "We chose journalism because we don’t have to deal with numbers" (cited in Maier 2002: 508).
} 
"numeracy” in the broad sense of the term "quantitative literacy," which has been described as:

\begin{abstract}
the ability to adequately use elementary mathematical tools to interpret and manipulate quantitative data and ideas that arise in individuals' private, civic and work lives (Gillman 2006: vii).
\end{abstract}

That is, "numeracy" and "quantitative literary" are taken to be ontological terms designating a stance towards the world, rather than epistemological terms delimiting a sphere of knowledge or competency. Hence any training which aims to bolster the ability to reason with number is considered in this paper, not merely training which is explicitly labelled "numeracy" or "mathematical." Many studies have identified the specifically journalistic shortcomings caused by an inadequate degree of numeracy (e.g., Paulos 1996; Genis 2001; Maier 2002). In his Final Report for the Royal Statistical Society, Frank Swain, National Coordinator for Science Training for Journalists, pointed out that "an understanding of numbers and statistics are key to many of the common errors in reporting science" (Swain 2012: 2). So, perhaps surprisingly, little attention has been paid to the issue of whether, how and when journalists are trained in numeracy, and its history is often overlooked. It is true that the history of quantitative literary and numeracy is receiving increased attention, particularly in the US (e.g., Steen 2001; Gillman 2006; Madison and Steen 2008), but this takes a broad view and rarely focuses on journalism as a discipline. On the other hand, research into numeracy training for journalists is often equally unforthcoming on the topic's history (e.g., Genis 2001; Ranney et al. 2008). The consequences for journalism of an inadequate grounding in quantitative literacy are two-fold - on the one hand, stories may be distorted or misleading; but on the other hand (and the more insidious because less flagrant), some stories may be under-reported or not reported on at all.

\title{
The Rise of Journalism Education
}

Journalism education itself emerged as a discipline in the UK only in the second half of the $20^{\text {th }}$ century, and it was a further 30 years before the history of this training attracted serious academic interest. But even today, little or no attention has been paid to the specific area of the history of numeracy training for journalists, despite the oft-repeated acknowledgment that numbers are the language of public discourse and the recent incursion of numeracy into traditionally unrelated domains, such as that of politics (e.g., Meyerson 2002) - a worldview opened up by Morris Kline's examination of the role mathematics plays in wider cultural development (Kline 1982).

The development of any form of training for journalists is inexorably linked to the establishment of journalism as a profession, with its own codes, standards and practices. This is not to say that newspapers prior to the $20^{\text {th }}$ 
century shied away from using numbers when reporting. The first edition of the Manchester Guardian in May 1821 published a table of school sizes in the Manchester area which had been 'leaked' by a credible source to show that official estimates of the number of children receiving free education were onethird of the true figure (Manchester Guardian 1821). However, there appears to be no journalistic intervention in either the compilation or interpretation of these data - it was submitted by an external source and printed without comment.

Arthur Christiansen, pioneering editor of the Daily Express in its post-war pomp, boasted rather than bemoaned the fact that, upon leaving school in 1920, "of maths I knew nothing and cared less" (Christiansen 1961: 11), while Daily Mirror editorial director Hugh Cudlipp noted that: "Anything I did not learn as a reporter in Blackpool [...] I learned by ear on the Sunday Pictorial" (Cudlipp 1962). Sunday Times journalist Leonard Ross, in his contribution to Modern Journalism, advised: "A good education, with the command of a couple of modern languages, makes an excellent foundation on which the beginner can build stone by stone, as he enlarges his experience not only of literature but of the world around him" (Carr and Stevens 1946: 216).

The first real steps in the gradual professionalisation of journalism came with the establishment of the UK's first academic qualification, the Diploma in Journalism offered by the University of London between 1919 and the outbreak of World War II. The curriculum was focused on journalism practice, with optional courses in politics, criticism, literature, history or modern languages - again, biased towards the liberal arts. One course was entitled 'General history and development of science', but it was not compulsory (Carr and Stevens 1946: 10).

As Frost observes: "The immediate post-war period ... lacked almost any kind of formal training or education for journalists in the UK” (Frost 2011: 6), a point reinforced by Briggs' and Burke's survey of the period: "Between 1919 and 1939 the only University Diploma for Journalism in Britain was offered at London University" (Briggs and Burke 2005: 165). The void was filled by an editorial training scheme launched in 1949 by Kemsley Newspapers, at the time the largest newspaper group in the country (Camrose 1947: 65) and which included the Sunday Times, Daily Graphic and Daily Record among its portfolio of eight morning, nine evening, and six Sunday titles, along with regional weeklies.

Viscount Kemsley's right-hand man at the time was Denis Hamilton, later editor-in-chief of the Sunday Times, who explained that political rather than professional motives lay behind the scheme's inception. Hamilton was aware that the Royal Commission on the Press, set up in 1947, could be damaging to the group's interests. The Labour government, and particularly home secretary Herbert Morrison, were overtly hostile to the right-wing press barons Kemsley and Beaverbrook heading the list - and one of the aims of the Royal Commission was to investigate political bias in the press. Determined to bolster his employer's reputation, Hamilton hit upon the idea of launching the 
Kemsley Editorial Training Plan, which by 1950 had the desired effect of transforming Kemsley into "the standard-bearer of his profession" (Hamilton 1989: 67), alongside the more far-reaching consequence of giving "a new professional status to the industry" (op cit. 70).

The significance of the Kemsley initiative lies in the fact that it was a deliberate attempt to pre-empt the recommendations of the Royal Commission, which asserted that journalists ought to be better educated than the public they served. Yet there is virtually nothing in the 424-page Kemsley tome concerning numeracy or quantitative literacy, apart from a passing reference to economics in a short (three-page) chapter on the role of the City editor. When it comes to recommended reading for trainee journalists, it is to the Bible, Shakespeare and Macaulay that the manual directs the aspiring reporter (Kemsley 1950: 398). But the author of that section (the journalist and historian Robert Ensor) does end with two 'special pleas' - one being for the history of science. "The journalist cannot be expected to know the sciences," he breezily asserts, "but he badly needs to know something of the history of scientific development” (op cit. 402). (His second 'special plea' was for poetry).

However, a breakthrough of sorts had occurred the year before the Royal Commission was established, in 1946. At a special delegate meeting, the National Union of Journalists (NUJ) had put forward their own training scheme, the academic components of which included English, geography and modern history (Kenyon 1948: 75). But significantly, this three-year curriculum also included "finance and statistics for journalists" - this topic is then singled out for extended treatment, since "the profession attracts men and women with a literary bias and many of them meet difficulties (which they do not always overcome) in handling figures". The eight sub-headings into which the topic is broken down include elementary mathematics, finance, and social and economic statistics. It is explicitly observed that this part of the curriculum is not intended solely for those who intend to specialise in financial or business reporting, but aimed at the general reporter, since the modern world "cannot be reported by journalists who do not understand figures” (op cit. 76).

The point is reinforced in his introduction by Ernest Jay, then NUJ president, who in listing the qualities of the ideal 'journalist of the future' pronounced: "Statistics, which to most people appear to be dry, meaningless tables of figures, must be to him alive with interest and possibility. He must be able to take them and translate them into vivid, factual commentaries on Life." (op cit. 8). This appears to be the earliest explicit reference to the difficulties those with a literary bent had in dealing with facts and figures, although even then it was clearly not a new problem. Yet this was not a development which was immediately built upon. The syllabus of the three-year basic training course proposed by the NCTJ's precursor, the National Advisory Council for 
the Training and Education of Junior Journalists ${ }^{2}$, was handily summarised in a 1951 'Teach Yourself' textbook aimed at aspiring journalists (Candlin 1955: 35-40). The emphasis is again on English, which appears across all three years of the curriculum - optional subjects are limited to "a modern language or an approved subject in social studies ... The term social studies is taken to include history, geography, economics, etc." It is acknowledged that those with "a scientific bent" may choose to specialise in science reporting, but the topic receives no more attention than reporting on the countryside (and less than that devoted to sports reporting or book reviewing) - and no specific training is recommended.

\section{The Importance of Being Precise}

The landmark publication came, not from the UK, but from across the Atlantic in 1973 when Philip Meyer published his Precision Journalism - now into its fourth edition (Meyer z02) - and popularised the concept of what was known at the time as computer-assisted reporting (CAR $)^{3}$. The advent of cheap computing power and the free availability of enormous government data-sets meant reporters were able to source stories by analysing and interpreting databases. Indeed, Meyer asserted that: "A journalist has to be a database manager, a data processor, and a data analyst” (Meyer 2002: 1). The significance of Meyer's work was not so much that UK universities rushed to set up courses in data-driven journalism (by and large, they didn't) but that numeracy rose higher on the agenda of journalism educators. The focus on numeracy training is evidenced by the fact that today a journalism textbook aimed at the general reporter devotes a substantial chapter to working with numbers (Chapter 4: "Facts and Figures: The Story has to Add Up"), which contains the admonition: "If you thought getting into journalism was a good career choice because you hated doing maths at school, think again" (Grundy et al. 2012: 96).

Until the late 1980s, it remained true that most UK journalists were trained by their employers (typically the regional press) as part of the proprietors' obligations under the national agreement between the Newspaper Society and the NUJ (Gopsill and Neale, cited in Frost 2011). As Mansfield explained: "The vast majority of journalists begin their training on the weeklies" (Mansfield 1944: 25). However, the ending of the national

\footnotetext{
${ }^{2}$ The NCTJ was originally set up under the name of the National Advisory Council for the Training and Education of Junior Journalists in November 1951, and changed its name to the National Council for the Training of Journalists in 1955. Hamilton (op cit. 69) gives the date as 1952 but this is presumably a mis-recollection.

${ }^{3}$ Meyer notes that in an age when computers were exciting and esoteric, newspapers loved to refer to 'computer-assisted reporting'; but now that we live in a "world where almost everything is computer assisted, that no longer means a lot” (op cit. 79) - although he does go on to point out that the phrase was in use as late as 2001.
} 
agreement in 1987 meant cost-conscious employers closed their training schemes, with the result that only "a small number of training courses are now run by newspaper groups, mixing basic journalism training with company induction" (Frost 2011: 11).

The current picture remains mixed; while educators are far more conscious of numeracy as a core journalistic skill and some research is being carried out (e.g., Genis 2001), delivery via the curriculum tends to rely on occasional lectures, workshops or master classes rather than being consistently woven into the degree programme. For instance, the UK universities' admissions body, the Universities and Colleges Admissions Service (UCAS), listed 82 providers offering 443 undergraduate courses in journalism for $2014 .^{4}$ While many undergraduate journalism programmes include elements of numeracy training, it appears that only one institution offers a joint programme in mathematics and journalism. ${ }^{5}$

The three main accreditation bodies for journalism are the NCTJ, the Broadcast Journalism Training Council (BJTC), and the Periodicals Training Council (PTC). The NCTJ's qualification specification for its Diploma in Journalism lists 22 learning outcomes for its News Reporting unit, but there are no references to numeracy or numerical skills (NCTJ 2013). Numeracy does feature as one of the 18 key tasks the NCTJ requires for its Reporter's Logbook (part of the body's National Certificate examination): "Submissions should demonstrate basic numeracy - the ability to handle figures, understand tables or interpret statistics, for example" (NCTJ 2011) - even here, however, evidence of numeracy is only one of nine marking criteria for this task. The Broadcast Journalism Training Council (BJTC) lists within its accreditation schema 13 "essential elements" of journalism skills and although these include accuracy and clarity, there is again no specific mention of numeracy (BJTC 2013). The PTC's magazine MagScene is aimed at budding magazine journalists ("This guide hopes to give you a taste of the variety of job opportunities available to you within consumer and business media”). Among the advice is a reply to the question, what skills other than writing are required to be a good journalist?

\begin{abstract}
You need to be enthusiastic, determined, have great ideas and you need to be able to get things done. Incredibly talented writers simply don't make it if they can't meet their deadlines. In an age of multi-media journalism you also need to be skilled across a range of platforms, as well as be the face of your magazine at various events and networking functions. All round communicators are in strong demand (MagScene 2013: 30).
\end{abstract}

Sound as this advice is, numeracy doesn't rate a mention.

\footnotetext{
${ }^{4}$ UCAS website. http://www.ucas.com/ (last access for this and other websites in these footnotes: 5/13/2014).

${ }^{5}$ University of Herfordshire, "Mathematics and Journalism \& Media Cultures, BSC/BA (Hons) http://www.herts.ac.uk/courses/mathematics-and-journalism-and-media-cultures.
} 
The Society of Editors, which as its name suggests represents senior editorial executives within the press and broadcast sector, gives advice for aspiring journalists on its website. It lists, not surprisingly, public administration, shorthand and ethics as core requirements, followed by "news sense, general knowledge, interviewing ability and news writing” (SoE 2013) but not numeracy. Creative Skillset, the UK's licensed Sector Skills Council for journalism, aims to support the industry's productivity by, among other things, informing and influencing "the development of qualifications for the competitive benefit of the Creative Industries." ${ }^{6}$ It has published an extensive suite of occupational standards for journalism, designed to provide a clear, up to date description of what an individual needs to be able to do in order to perform a job successfully (Skillset 2014). The Skillset standards identify core capabilities which all employers demand, regardless of changes in technology or working practice. These include attributing data sources accurately, and the "need for accuracy in spelling." There is no similar injunction against numerical inaccuracy. ${ }^{7}$ The only reference to handling quantitative information comes in the standard on undertaking research, where emphasis is placed on "how to analyse and interpret relevant data," 8 and the standard on measuring the effectiveness of editorial content. ${ }^{9}$

The key role of universities in training journalists was made clear in evidence submitted to the UK's Leveson Inquiry in press standards, following the telephone hacking scandal which led to the closure of Rupert Murdoch's Sunday tabloid, The News of the World. The Association for Journalism Education (AJE), which represents approximately 60 higher education institutions in the UK and Ireland, pointed out that the industry has largely withdrawn from the provision of training, leaving it primarily to higher education institutions: "Only a small number of training courses are now run by newspaper groups, mixing basic journalism training with company induction" (AJE 2012: 4). A major factor behind this withdrawal is undoubtedly cost. Sue Ryan of the Daily Mail explained to Leveson: "The trainee scheme costs the Mail well over half a million pounds a year. I know of no other newspaper group that spends anything like this sum training its journalists” (Ryan 2012: 5). This suggests that provision of numeracy training for journalism students - at undergraduate level, at least - is ad hoc and patchy. As a report produced for the Royal Statistical Society put it: "There is little statistics or science content in most general journalism courses, although most journalism trainees do not have a numerical or scientific background" (Swain 2012: 42) - and while statistics or science content is not synonymous with numeracy, there is a considerable degree of overlap, particularly as the RSS

\footnotetext{
${ }^{6}$ Creative Skillset website.http://creativeskillset.org/about_us

${ }^{7}$ http://nos.ukces.org.uk/PublishedNos/SKSJ14.pdf\#search=journalism

8 http://nos.ukces.org.uk/PublishedNos/SKSJ9.pdf\#search=journalism

9 http://nos.ukces.org.uk/PublishedNos/SKSJ35.pdf\#search=journalism
} 
report identified a key area of concern as that of reporters "feeling comfortable with numbers” (Swain op. cit.).

\section{Discussion: Consequences Beyond the Academy}

Given that journalists and journalism students alike display a marked antipathy to quantitative literacy, why does it matter? What are the consequences for our newspapers, our daily discourse and the way we live our lives if reporters exhibit a phobia for figures? As alluded to in the Introduction, there are two main dangers - misreporting and under-reporting. Misreporting can flow from several sources, such as errors in numerical manipulation or the use of inappropriate methodologies. Maier (2002) identified 11 categories of error in his inventory of 2,000 stories from local US daily newspapers. In the UK, the BBC radio programme More Or Less chronicles similar instances of journalistic innumeracy, ranging from the amusing to the astonishing. To take a relatively benign example - during the 2010 soccer World Cup, it was widely reported that a 'psychic' octopus named Paul had correctly 'predicted' the result of several matches, including the final, by its movements in a tank conveniently ignoring the massed ranks of cephalopods and assorted invertebrates which doubtless made similar 'predictions' that were never reported because they were wrong. To anyone unfamiliar with the mathematics of co-incidence, Paul's feat may well appear magical - but as Eastaway and Wyndham (1999) point out: "Boring incidents are quickly forgotten, but coincidences grab the attention and stick in the mind" (p. 52).

To give a more serious example, the reporting of opinion polls is often incomplete, with a key piece of information - the margin of error - routinely omitted. In the run-up to the UK general election in 2010, the Daily Mirror gave the results of a voting-intention poll which put the Conservative Party on 35\% and the Labour Party on 30\% (Roberts, 2010). It was only by visiting the website of pollsters Ipsos Mori ${ }^{10}$ that the margin of error could be found. It was $4 \%$, making the difference between the parties far less clear-cut. The polling organisation's website even went so far as to point out that the margin of error "is especially important to keep in mind when calculating party lead figures" - a point which was evidently lost on the journalists of the Daily Mirror. A final example is from a numeracy test administered to 32 journalism undergraduates by the present author in September 2013. One question asked for the percentage change in the number of medals won by Team GB in the 2012 London Olympics compared to 2008, given that the team won 47 medals in 2008 and 65 in 2012. Only four students gave the correct answer; efforts ranged from $2 \%$ to $50 \%$.

This question was not even attempted by 11 of the students, which leads to the second consequence of poor levels of quantitative literacy - the underreporting or non-reporting of stories which involve figures. Sins of omission

${ }^{10}$ Ipsos MORI website. www.ipsos-mori.com 
are far more difficult to detect, and hence to remedy, than sins of commission and by the very nature of the problem, it is a difficult one to quantify. However, in the author's own 25-year experience of reporting for regional UK newspapers, it became clear that stories which involved some level of numerical complexity - such as school league tables, adjustments to local taxation, or financial news - would not be assigned to specific reporters because news editors feared they would not be able to comprehend the story adequately. On occasion, this could result in news stories being held back until a suitable reporter was available. It is hypothesised that in extremis this could also result in stories going unreported, although further research would be required to substantiate this.

Turning now to the systemic implications, it is clear that training (and education - to which it is inescapably if not unproblematically linked), like numeracy, is neither ideologically pure nor institutionally neutral. Just as numbers are embedded in political, philosophical and bureaucratic systems (Alonso and Starr 1987), so too is academic instruction - we teach what we've been taught to teach. So while the debate concerning quantitative literacy has moved centre stage in the US - with a raft of initiatives aimed at plugging the 'QL gap' among liberal arts students (Gillman 2006) - discussion in the UK is less well developed. Not all numeracy training initiatives have originated from within academia or the journalism profession. A training programme was launched by the Royal Statistical Society (RSS) with the aim of "helping trainee and practising journalists to develop a better grasp of the basic principles and methods of statistics” (RSS Stats Life n.d.). This followed the publication of the report of the expert group Science and the Media (2010), under the auspices of the Department for Business, Innovation and Skills (BIS), and subsequently updated (Science and the Media 2012). The specific goal of the RSS project was to improve science reporting, but it was acknowledged that in order to achieve this, the objective should be on fostering "greater scientific literacy in the whole journalistic community" (Science and the Media 2010). As the Final Report on the project noted:

This project has focused on basic training for non-specialist reporters and journalism students, and has identified that an understanding of numbers and statistics are key to many of the common errors in reporting science (as well as other subjects). (Swain 2012).

Other outcomes identified by the BIS expert group have included the development of resources on the BBC College of Journalism website, ${ }^{11}$ and similar websites created by the Online Media Group for Science ${ }^{12}$ and the RSS. ${ }^{13}$ In addition, the UK charitable organisation National Numeracy provides training material and funds research with the objective of ensuring everyone reaches "a level of functional numeracy appropriate to their daily

${ }^{11}$ BBC Academy website. www.bbc.co.uk/academy/journalism

${ }^{12}$ Online Media Group for Science website. www.omg-science.org.uk

${ }^{13}$ Royal Statistical Society, StatsLife website. www.statslife.org.uk/resources/for-journalists 
life."14 Valuable though they may be, online resources by themselves do not constitute training, and the issue remains of who delivers this training and within what context(s): "In general, it has been difficult to identify places where journalists go for on-the-job training and where science/stats training could be institutionalised" (Swain op. cit.).

Finally, while this paper has considered the training of the general news journalist, it should not be forgotten that specialist reporters dealing with business, commodities, and shipping have been in existence since at least the $18^{\text {th }}$ century (Lloyd's List, for example, has been published since at least 1734 and had predecessors). The Financial News was established in 1884, later to merge with its younger rival the Financial Times, and specialised in reporting of the financial, commodity, and exchange markets. This meant reporters had to be specialised, too: "Business reporting involves many beats, and journalists who cover business tend to be specialists" (Thompson 2001: xi). But even here, the lack of quantitative competency can still be felt. "Since many of us who studied journalism or selected it as a profession did so to avoid mathematics, a 'math phobia' permeates the field” (op cit. xii).

\section{Conclusion}

Despite its universally acknowledged importance, there has been no sustained, consistent approach to the provision of numeracy training for UK journalists or journalism students. While some important work has been done on how a quantitative approach can best be engendered among a group who traditionally shy away from thinking with figures (e.g., Gillman 2006; Ranney et al. 2008), the institutional and organisational aspects remain ill-defined. This is not helped by a lack of emphasis from training and skills bodies on quantitative literary as a way of interpreting the world. Since journalism educators are themselves generally drawn from the ranks of the profession, the inadequacies which flow from quantitative illiteracy may continue to be perpetuated. The way in which journalism trainers are themselves trained is a key variable in this equation. Without addressing this question, a key element of journalism's mission to explain can be only partially fulfilled.

\section{References}

JE, 2012. Journalism training and education and its part in the culture, practices, standards and ethics of the press: Evidence from the Association for Journalism Education. http://www.levesoninquiry.org.uk/wpcontent/uploads/2012/02/Submission-by-Association-for-Journalism-EducationLiverpool-John-Moores-University.pdf (Accessed August 4 2013).

Alonso, W., and P. Starr (Eds.). 1987. The Politics of Numbers. Russell Sage Foundation, New York.

\footnotetext{
${ }^{14}$ National Numeracy website. www.nationalnumeracy.org.uk
} 
BJTC, 2013.

http://www.bjtc.org.uk/uploads/accreditationPdfs/16/BJTC Guidelines Updated _October_2013.pdf (Accessed April 25 2014).

Briggs, A. and Burke, P. 2005. A Social History of the Media: From Gutenberg to the Internet. Wiley, London.

Camrose. 1947. British Newspapers and their Controllers. Cassell, London.

Candlin, E.F. 1955. Teach Yourself Journalism. English Universities Press, London.

Carey, J. W. 2000. Some personal notes on US journalism education. Journalism, 1: 12-23. http://dx.doi.org/10.1177/146488490000100103 (Accessed May 13, 2014)

Carr, C.F., and F.E. Stevens. 1946. Modern Journalism: A complete guide to the newspaper craft. Sir Isaac Pitman and Sons, London.

Christiansen, A. 1961. Headlines All my Life. Heinemann, London.

Cudlipp, H. 1962. At Your Peril. Weidenfeld and Nicolson.

Dearing Report. 1997. Higher Education in the Learning Society. National Committee of Inquiry into Higher Education. HMSO, London. http://www.leeds.ac.uk/educol/ncihe/ (accessed 4/24/2014)

Eastaway, R., and J. Wyndham. 1999. Why Do Buses Come in Threes? The hidden mathematics of everyday life. Robson Books, London.

Frost, C. 2011. Journalism and its move into the academy. Unpublished manuscript.

Genis, A. 2001. Numbers Count: The Importance of Numeracy for Journalists. Unpublished M. Phil dissertation, South Africa: University of Stellenbosch.

Gillman, R. (Ed.). 2006. Current Practices in Quantitative Literacy. Mathematical Association of America, USA.

Grundy, B., M. Hirst, J. Little, M. Hayes, and G. Treadwell. 2012. So you want to be a journalist? Unplugged, 2nd ed. Cambridge University Press, Cambridge. http://dx.doi.org/10.1017/CBO9781139519410

Hamilton, Sir Denis. 1989. Editor-in-Chief: The Fleet Street Memoirs of Sir Denis Hamilton Hamish Hamilton, London.

Kemsley. 1950. The Kemsley Manual of Journalism, 1st ed. Cassell and Co Ltd, London.

Kenyon, A. (Ed.). 1948. Entry into Journalism: A guide for students, and for educationalists and others advising on careers. Medallion Press, London.

Kline, M. 1982. Mathematics and Western Culture. Pelican, London.

Madison, B. and L.A. Steen, L. 2008. Evolution of numeracy and the National Numeracy Network. Numeracy 1 (1): Article 2. Available at http://dx.doi.org/10.5038/1936-4660.1.1.2 (Accessed August 9 2013)

MagScene 2013. http://www.ppa.co.uk/jobs-careers-and-training/the-periodicalstraining-council-ptc/ /media/Documents/Training/Magscene/MagScene.ashx

Maier, S. R. 2002. Numbers in the News: a mathematics audit of a daily newspaper. Journalism Studies, 3:4, 507-519. Routledge. http://dx.doi.org/10.1080/1461670022000019191 (Accessed 4/24/2014)

Manchester Guardian. 1821. To the Editor of the Manchester Guardian. Available from http://image.guardian.co.uk/sysfiles/Guardian/documents/2011/09/25/ManchesterGuardianback.pdf (Accessed September 1 2013)

Mansfield, F. J. 1944. The Complete Journalist: A Study of the Principles and Practice of Newspaper-Making, $2^{\text {nd }}$ ed. Isaac Pitman and Sons, London. 
Mencher, M. 1995. Young journalists are terrified by numbers. Editor \& Publisher, 128(47): 48. 25. Cited in Maier, 2002.

Meyer, P. 2002. Precision Journalism: A reporter's introduction to social science methods, 4th ed. Rowman and Littlefield, Maryland, USA.

Meyerson, M. 2002. Political Numeracy: Mathematical Perspectives on our chaotic constitution. Norton, New York.

National Council for the Training of Journalists. 2011. NCE Logbook Guidelines for candidates, trainers and examiners.

http://www.nctj.com/downloadlibrary/logbook_guidelines_for_reporters1.pdf (Accessed August 1 2013).

National Council for the Training of Journalists. 2013. http://www.nctj.com/downloadlibrary/Diploma in Journalism qualification specification.pdf (Accessed April 25 2014).

NCTJ. See National Council for the Training of Journalists.

OECD, 2013. OECD Skills Outlook 2013. http://www.oecd.org/site/piaac/Skills\%20volume\%201\%20\%28eng\%29-full\%20v12--eBook\%20\%2804\%2011\%202013\%29.pdf (Accessed April 25 2014).

Paulos, J. A. 1996. A Mathematician Reads the Newspaper. Penguin, London.

Randall, D. 2007. The Universal Journalist. Pluto, London.

Ranney, M. A., Rinne, L. F., Yarnall, L., Munnich, E., Miratrix, L., Schank, P., 2008. Designing and assessing numeracy training for journalists: Toward improving quantitative reasoning among media consumers. International Perspectives in the Learning Sciences. Proceedings of the Eighth International Conference for the Learning Sciences, Vol. 2. International Society of the Learning Sciences, Inc.

Roberts, Bob. 2010. David Cameron in Tory poll plunge shocker which says Labour and Gordon Brown would win General Election. Daily Mirror, May 24. http://www.mirror.co.uk/news/uk-news/david-cameron-in-tory-poll-plunge210135 (Accessed February 17, 2014).

RSS Stats Life, n.d. Resources for Journalists. http://www.statslife.org.uk/resources/for-journalists (Accessed October 16 2013).

Ryan, S., 2012. http://www.levesoninquiry.org.uk/wpcontent/uploads/2012/02/Witness-Statement-of-Sue-Ryan.pdf (Accessed August 4 2013).

Science and the Media, 2010. Science and the Media: Securing the Future. Science and the Media Expert Group. Department for Business, Innovation and Skills http://webarchive.nationalarchives.gov.uk/tna/+/http:/www.bis.gov.uk/wpcontent/uploads/2010/01/Science-and-the-Media-Securing-Future.pdf/ (Accessed October 12 2013).

Science and the Media, 2012. Science and the Media Action Plan Update. Department for Business, innovation and Skills http://scienceandsociety.bis.gov.uk/media/files/2012/09/Copy-of-D12-1122172Science-and-the-Media-Action-Plan-Update-September-2012.xls (Accessed October 12 2013).

Skillset. 2014. http://creativeskillset.org/ (Accessed April 25 2014)

Steen, L.A., 2001. Mathematics and Democracy: The case for quantitative literacy. National Council on Education and the Disciplines, USA. 
SoE, 2013.Society of Editors and Training. Society of Editors.

http://www.societyofeditors.co.uk/page-view.php?pagename=TrainingJournalists (Accessed August 7 2013).

Swain, F., 2012. Science Journalism: Final Report of the National Coordinator for Science Training for Journalists. Royal Statistical Society. Report supplied to author.

Thompson, T. (ed.), 2001. Writing about Business: The New Columbia KnightBagehot Guide to Economics and Business Journalism. Columbia University Press, New York. 